\title{
Primary malignant melanoma of the gall bladder
}

\author{
D I HEATH, ${ }^{*}$ C WOMACK $\dagger$
}

From the Departments of * Surgery and †Pathology, Peterborough District Hospital, Peterborough

SUMMARY A case of primary malignant melanoma of the gall bladder is reported, in which a 29 year old man presented with acute cholecystitis which led to perforation of the gall bladder and biliary peritonitis. To help in the differentiation between primary and secondary malignant melanoma in the gall bladder and to overcome some of the difficulties posed by the clinical identification of what is often a small or relatively inaccessible primary tumour, it is suggested that certain criteria should be fulfilled before primary melanoma is diagnosed. (i) Tumours must be solitary and arise from the mucosal surface of the gall bladder; (ii) they must either be papillary or polypoid; (iii) they must either display junctional activity or have any other primary sites excluded by history taking, examination, and investigation.

If these criteria are applied to the published case reports of primary malignant melanoma, only six cases, including the present one, can be regarded as true primary tumours.

Primary malignant melanoma of the gall bladder is extremely rare, only 20 cases having been described in the world. ${ }^{1-17}$ We report a patient who presented with acute cholecystitis, which led to perforation of the gall bladder and biliary peritonitis. This presentation has not previously been described as far as we know.

Accepted for publication 5 May 1988

\section{Case report}

A 29 year old man was admitted as an emergency with a one week history of right hypochondrial pain. On examination his temperature was $38^{\circ} \mathrm{C}$ and was tender in the right hypochondrium, with a positive Murphy's sign. His white cell count was $14000 \times 10^{9} / 1$. Estimation of serum amylase activity and liver function tests were normal. Plain abdominal $x$ ray pictures showed a

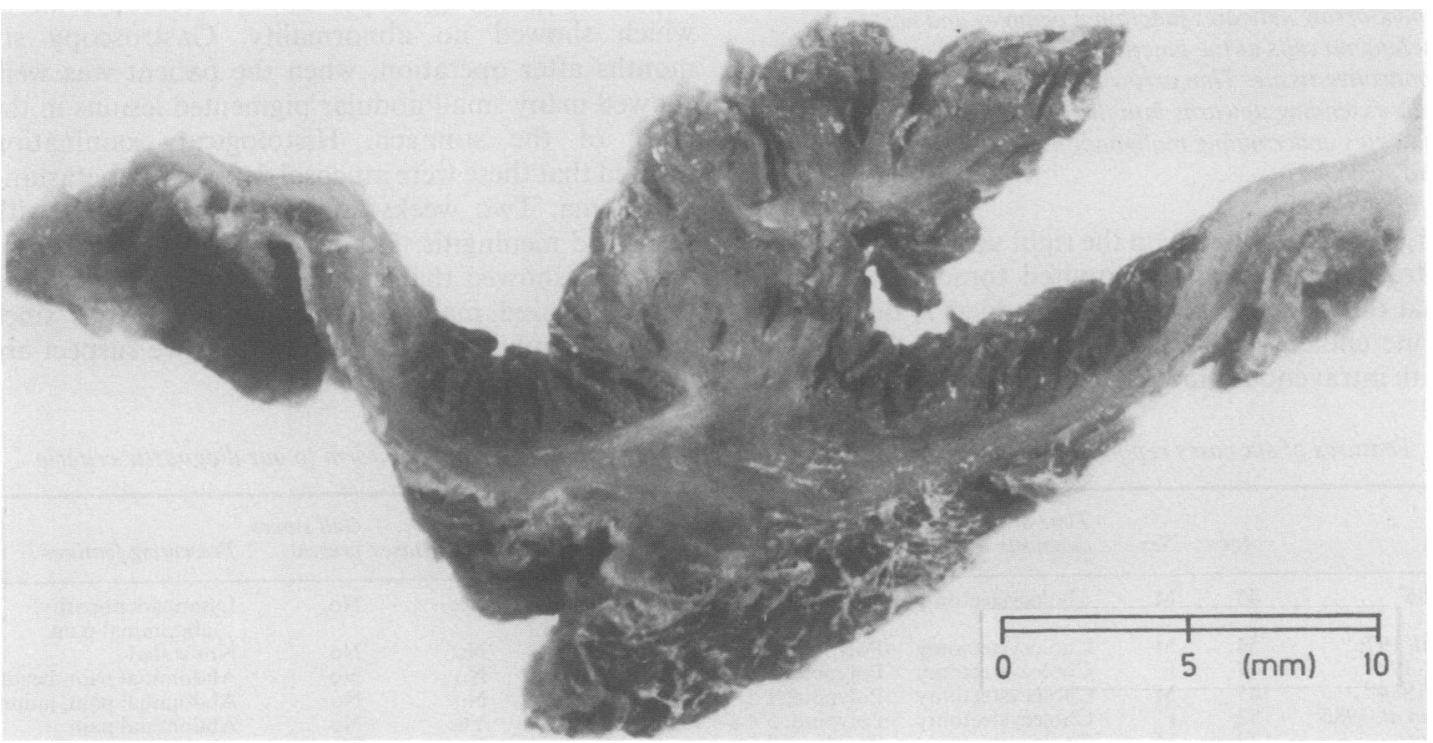

Fig 1 Primary malignant melanoma of the gall bladder: macroscopic features. 


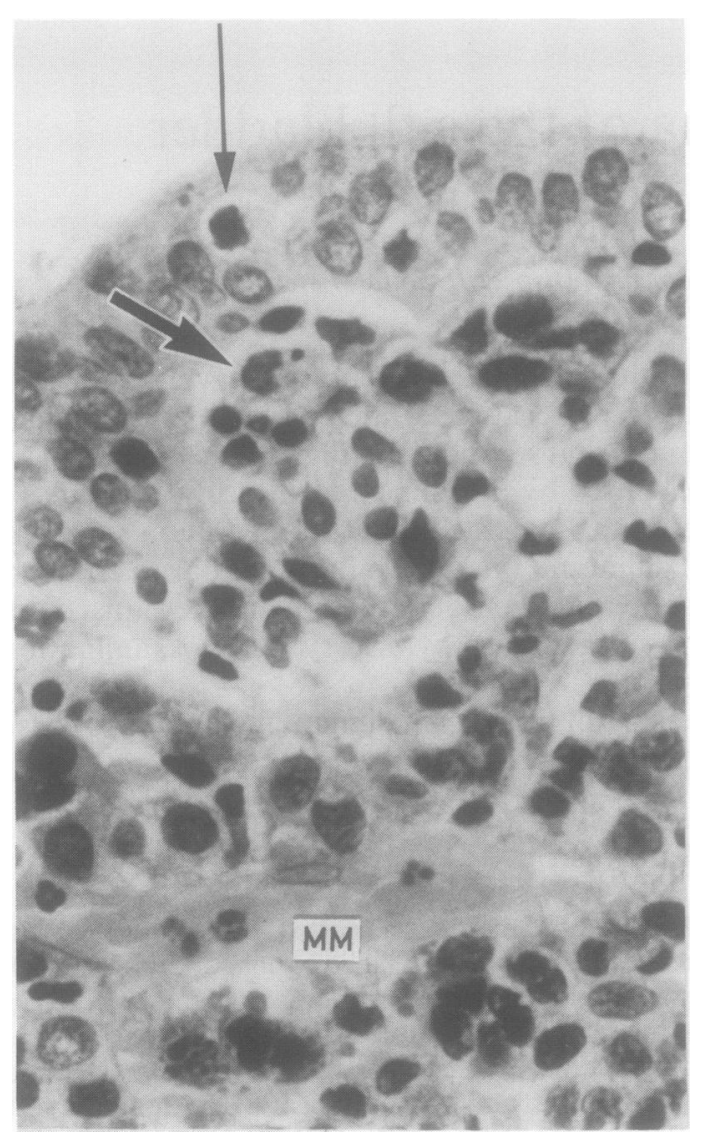

Fig 2 Primary malignant melanoma of the gall bladder. Thick arrow indicates junctional changes and nests of melanoma cells at the junction of the epithelium and connective tissue. Thin arrow indicates individual melanoma cells extending upwards into the gallbladder epithelium. MM indicates undermining malignant melanoma. (Haematoxolin and eosin.)

large rounded opacity in the right upper quadrant. An ultrasound scan and computed tomograms showed that this opacity was the gall bladder. A diagnosis of acute cholecystitis was made and the patient treated with intravenous fluid replacement and antibiotics. On the fifth day he developed generalised peritonitis and underwent a laparotomy at which a grossly distended, perforated gall bladder was removed. A hard nodule was palpated at the fundus of the gall bladder, and because malignancy was suspected a careful search was made of the abdomen; no tumour deposits were found. There were no gall stones. Peroperative cholangiography was not carried out for technical reasons.

The opened gall bladder, fixed in formol saline, was $9 \mathrm{~cm}$ long, $3.5 \mathrm{~cm}$ in diameter, and the wall was $1.8 \mathrm{~cm}$ thick. There was an irregular haemorrhagic perforation at the proximal end and a dark papillary mucosal nodule $2.5 \mathrm{~cm}$ in diameter at the fundus (fig 1). No lymph nodes were included in the specimen. The perforation was confirmed on histological examination; there were changes consistent with chronic cholecystitis and a high proportion of eosinophils in the inflammatory infiltrate. The papillary lesion at the fundus was a malignant melanoma, confined to the lamina propria without invasion of the muscular wall. Junctional activity - that is, the presence of microscopic aggregates of melanoma cells at the junction of epithelium and lamina propria-was present (fig 2). Tumour cells within the epithelium, as well as in the main body of the growth, stained positively for $\mathrm{S} 100$ protein and vimentin using a standard immunoperox idase technique, and contained dark brown pigment that stained as melanin pigment with Masson Ham perl.

After the histological diagnosis had been made a thorough search was made for an alternative primary site. This included examination of the skin, proctoscopy, nasopharyngoscopy, and fundoscopy, all of which showed no abnormality. Gastroscopy six months after operation, when the patient was well, showed many small nodular pigmented lesions in the body of the stomach. Histological examination showed that these were mucosal deposits of metastatic melanoma. Two weeks later he was admitted with suspected meningitis. Examination of the cerebrospinal fluid showed that it contained melanocytes and was diagnosed malignant meningitis. He has since developed subcutaneous nodules that we suspect are further deposits of melanoma.

Table 1 Features of six cases reported as primary malignant melanoma of the gall bladder that conform to our diagnostic criteria

\begin{tabular}{|c|c|c|c|c|c|c|c|c|}
\hline Author & Age & Sex & $\begin{array}{l}\text { Time of } \\
\text { diagnosis }\end{array}$ & $\begin{array}{l}\text { Type and } \\
\text { size of tumour }\end{array}$ & $\begin{array}{l}\text { Junctional } \\
\text { activity }\end{array}$ & Metastases & $\begin{array}{l}\text { Gall stones } \\
\text { present }\end{array}$ & Presenting features \\
\hline Walsh, $1956^{5}$ & 45 & $\mathbf{M}$ & Cholecystectomy & Trilobular, $7.5 \times 2 \times 1 \mathrm{~cm}$ & Yes & Yes & No & $\begin{array}{l}\text { Lymphadenopathy, } \\
\text { abdominal pain }\end{array}$ \\
\hline $\begin{array}{l}\text { Pieson et al, } 1976^{11} \\
\text { Carle et al, } 1981^{13} \\
\text { Seul et al, } 1984^{15} \\
\text { Verbanck et al, } 1986^{17} \\
\text { Present case }\end{array}$ & $\begin{array}{l}54 \\
47 \\
45 \\
52 \\
29\end{array}$ & $\begin{array}{l}\mathbf{M} \\
\mathbf{F} \\
\mathbf{M} \\
\mathbf{F} \\
\mathbf{M}\end{array}$ & $\begin{array}{l}\text { Cholecystectomy } \\
\text { Cholecystectomy } \\
\text { Cholecystectomy } \\
\text { Cholecystectomy } \\
\text { Cholecystectomy }\end{array}$ & $\begin{array}{l}\text { Polypoid, } 4 \times 3 \mathrm{~cm} \\
\text { Polypoid, } 1.5 \mathrm{~cm} \\
\text { Polypoid, } 1.5 \times 1 \mathrm{~cm} \\
\text { Polypoid, } 5 \times 4 \times 4 \mathrm{~cm} \\
\text { Papillary, } 2.5 \times 2 \mathrm{~cm}\end{array}$ & $\begin{array}{l}\text { Yes } \\
\text { Yes } \\
\text { Yes } \\
\text { Yes } \\
\text { Yes }\end{array}$ & $\begin{array}{l}\text { No } \\
\text { No } \\
\text { No } \\
\text { Yes } \\
\text { Yes }\end{array}$ & $\begin{array}{l}\text { No } \\
\text { No } \\
\text { No } \\
\text { No } \\
\text { No }\end{array}$ & $\begin{array}{l}\text { Not stated } \\
\text { Abdominal pain, headach } \\
\text { Abdominal pain, jaundic } \\
\text { Abdominal pain } \\
\text { Abdominal pain }\end{array}$ \\
\hline
\end{tabular}


Table 2 Features of 15 cases reported as primary malignant melanoma of the gall bladder that do not conform to our diagnostic criteria

\begin{tabular}{|c|c|c|c|c|c|c|c|c|}
\hline Author & Age & Sex & $\begin{array}{l}\text { Time of } \\
\text { diagnosis }\end{array}$ & $\begin{array}{l}\text { Type and } \\
\text { size of tumour }\end{array}$ & $\begin{array}{l}\text { Junctional } \\
\text { activity }\end{array}$ & $\begin{array}{l}\text { Metastases } \\
\text { present }\end{array}$ & $\begin{array}{l}\text { Gall stones } \\
\text { present }\end{array}$ & Presenting features \\
\hline Weitung, $1907^{1}$ & 40 & $\mathbf{F}$ & Necropsy & Polypoid, $2.1 \times 2 \times 1.1 \mathrm{~cm}$ & Not stated & Yes & No & Back pain, paraplegia, \\
\hline Rosenthal, $1931^{2}$ & 48 & $\mathbf{M}$ & Necropsy & Papillary, $4.5 \times 4 \times 2 \mathrm{~cm}$ & Not stated & Yes & No & $\begin{array}{l}\text { weight loss, jaundice } \\
\text { Haematuria, headaches, } \\
\text { and convulsions }\end{array}$ \\
\hline Pautler et al, $1951^{3}$ & 65 & $\mathbf{M}$ & Necropsy & Polypoid, $4 \times 3 \times 3 \mathrm{~cm}$ & Not stated & Yes & No & $\begin{array}{l}\text { Headaches, hemiparesis, } \\
\text { weight loss }\end{array}$ \\
\hline Thayer et al, 19554 & 69 & $\mathbf{F}$ & Cholecystectomy & Papillary & Not stated & Yes & No & Abdominal pain, \\
\hline Jones, $1961^{6}$ & 72 & $\mathbf{M}$ & Necropsy & Polypoid, $6.5 \times 3 \times 3 \mathrm{~cm}$ & Not stated & Yes & No & $\begin{array}{l}\text { Haematemesis and } \\
\text { melaena }\end{array}$ \\
\hline $\begin{array}{l}\text { Raffensperger et al, } 1963^{7} \\
\text { Debiec et al, } 1966^{8} \\
\text { Simmard et al, } 1966^{\circ}\end{array}$ & $\begin{array}{l}46 \\
71 \\
74\end{array}$ & $\begin{array}{l}\mathbf{F} \\
\mathbf{F} \\
\mathbf{F}\end{array}$ & $\begin{array}{l}\text { Cholecystectomy } \\
\text { Cholecystectomy } \\
\text { Cholecystectomy }\end{array}$ & $\begin{array}{l}\text { Polypoid, } 11 \times 4 \mathrm{~cm} \\
\text { Sessile } \\
\text { Plaques, multiple, } 1.5 \mathrm{~cm}\end{array}$ & $\begin{array}{l}\text { Not stated } \\
\text { Not stated } \\
\text { Not stated }\end{array}$ & $\begin{array}{l}\text { Yes } \\
\text { No } \\
\text { Yes }\end{array}$ & $\begin{array}{l}\text { No } \\
\text { Yes } \\
\text { Yes }\end{array}$ & $\begin{array}{l}\text { Abdominal pain } \\
\text { Abdominal pain } \\
\text { Abdominal pain, right }\end{array}$ \\
\hline Sierra-Callejas et al, & $\begin{array}{l}71 \\
44\end{array}$ & $\begin{array}{l}\mathbf{M} \\
\mathbf{M}\end{array}$ & $\begin{array}{l}\text { Necropsy } \\
\text { Necropsy }\end{array}$ & $\begin{array}{l}\text { Multiple, small polypoid } \\
\text { Two polyps } 2 \cdot 2 \text { and } 2 \mathrm{~cm}\end{array}$ & $\begin{array}{l}\text { Not stated } \\
\text { Not stated }\end{array}$ & $\begin{array}{l}\text { Yes } \\
\text { Yes }\end{array}$ & $\begin{array}{l}\text { No } \\
\text { No }\end{array}$ & $\begin{array}{l}\text { Weight loss, jaundice } \\
\text { Jacksonian epilepsy }\end{array}$ \\
\hline $\begin{array}{l}\text { Pieson et al, 1976" } \\
\text { Hatae et al, 1978'12 } \\
\text { Borja et al, 1984 } \\
\text { Rudolph et al, } 1985^{16}\end{array}$ & $\begin{array}{l}58 \\
50 \\
72 \\
31 \\
51\end{array}$ & $\begin{array}{l}\mathbf{M} \\
\mathbf{M} \\
\mathbf{M} \\
\mathbf{M} \\
\mathbf{F}\end{array}$ & $\begin{array}{l}\text { Cholecystectomy } \\
\text { Cholecystectomy } \\
\text { Cholecystectomy } \\
\text { Cholecystectomy } \\
\text { Cholecystectomy }\end{array}$ & $\begin{array}{l}\text { Diffuse, polypoid } \\
\text { Polypoid, } 3 \times 2 \times 1.5 \mathrm{~cm} \\
\text { Solid } \\
\text { Polypoid, } 2 \mathrm{~cm} \\
\text { Polypoid, } 4.5 \times 3 \mathrm{~cm}\end{array}$ & $\begin{array}{l}\text { No } \\
\text { No } \\
\text { Not stated } \\
\text { Not stated } \\
\text { No }\end{array}$ & $\begin{array}{l}\text { No } \\
\text { Yes } \\
\text { Not stated } \\
\text { Yes } \\
\text { Yes }\end{array}$ & $\begin{array}{l}\text { No } \\
\text { No } \\
\text { No } \\
\text { No } \\
\text { No }\end{array}$ & $\begin{array}{l}\text { Not stated } \\
\text { Not stated } \\
\text { Abdominal pain } \\
\text { Abdominal pain } \\
\text { Recurrent abdominal } \\
\text { pain }\end{array}$ \\
\hline
\end{tabular}

The clinical and pathological features of all the reported cases of primary malignant melanoma of the gall bladder are shown in tables 1,2 , and 3.

\section{Discussion}

Extracutaneous primary malignant melanoma is known to occur in the retina, meninges, and nasal mucosa where melanocytes are normally present.

Table 3 Outcome of 16 of the patients detailed in tables 1 and 2

\begin{tabular}{|c|c|}
\hline Author & Outcome \\
\hline \\
\hline \multicolumn{2}{|c|}{ Walsh, $1956^{5}$} \\
\hline Case 2 & \multirow{2}{*}{$\begin{array}{l}\text { No follow up } \\
\text { Died of metastatic disease after } 3 \text { years } \\
4 \text { months }\end{array}$} \\
\hline Carle et al, $1981^{13}$ & \\
\hline Seul et al, $1984^{15}$ & Well after one year \\
\hline Verbanck et al, $1986^{17}$ & $\begin{array}{l}\text { Metastases in common bile duct } \\
\text { diagnosed after } 6 \text { months; well after } \\
9 \text { months }\end{array}$ \\
\hline Present case & $\begin{array}{l}\text { Widespread metastases diagnosed after } \\
7 \text { months }\end{array}$ \\
\hline \multicolumn{2}{|c|}{$\begin{array}{l}\text { Patients whose melanomas did not conform to our diagnostic } \\
\text { criteria: }\end{array}$} \\
\hline \multicolumn{2}{|c|}{ Pieson et al, 1976" } \\
\hline $\begin{array}{l}\text { Case } 1 \\
\text { Case } 3\end{array}$ & No follow up \\
\hline $\begin{array}{l}\text { Borja et al, } 1984^{14} \\
\text { Hatae et al, } 1978^{12}\end{array}$ & $\begin{array}{l}\text { Died of metastatic disease after } 9 \text { months } \\
\text { No follow up }\end{array}$ \\
\hline $\begin{array}{l}\text { Thayer et al, } 1955^{4} \\
\text { Jones, } 1961^{6}\end{array}$ & $\begin{array}{l}\text { Died two days after operation } \\
\text { Died of metastatic disease after } 2 \text { months }\end{array}$ \\
\hline Raffensperger et al, & Well after one year \\
\hline $\begin{array}{l}\text { Simmard et al, } 1966^{9} \\
\text { Rudolph et al, } 1985^{16} \\
\text { Debiec et al, } 1966^{8}\end{array}$ & $\begin{array}{l}\text { Died of metastatic disease after } 2 \text { months } \\
\text { Died of metastatic disease after } 7 \text { months } \\
\text { Alive after } 3 \text { months }\end{array}$ \\
\hline
\end{tabular}

Malignant melanomas at other extracutaneous sites are usually metastatic. The gall bladder is a common site for metastatic melanoma, ${ }^{18}$ and the primary tumour may be either small or in a comparatively inaccessible place, and thus escape clinical identification. Furthermore, cutaneous melanomas may undergo true spontaneous regression and there may be no primary to find, and therefore it can be exceedingly difficult to prove that a melanoma of the gall bladder is primary rather than secondary.

Primary malignant melanoma of the gall bladder is theoretically possible for a number of reasons. Firstly, melanocytes have been reported in normal gall bladder although their universal presence is not generally accepted. ${ }^{19}$ Secondly, it is possible that on rare occasions ectopic migration of melanocyte precursors may occur in embryos to sites where melanocytes are not normally found and subsequently give rise to melanoma. ${ }^{20}$ Thirdly, junctional activity, a prerequisite for the diagnosis of primary melanoma of mucous membranes, ${ }^{21}{ }^{22}$ was seen in six of the cases, including ours. ${ }^{611} 131517$

We consider that the following criteria must be satisfied before primary malignant melanoma of the gall bladder can be diagnosed: tumours must be solitary; arise from the mucosal surface of the gall bladder and be either papillary or polypoid; and must either display junctional activity or have any other primary sites excluded by thorough history taking, examination, and investigation.

There are no reliable macroscopic features to distinguish primary from secondary melanoma of the gall bladder. Most tumours reported as primary gall bladder melanomas are solitary, large, and either 
papillary or polypoid (table 1). Secondary deposits are characterised by Willis as being small, nodular, and multiple. ${ }^{23}$ Multiple tumours of the gall bladder are therefore unlikely to be primary and we can thus exclude the cases of Simmard $e t a P$ and Sierra-Callejas and Warecka, ${ }^{10}$ because these were probably metastatic. In two reports ${ }^{714}$ tiny nodules close to the main tumours were noted and it is not clear whether these were extensions of the primary tumours or metastatic deposits. There are also reports of patients with known primary tumours elsewhere ${ }^{24}$ who developed solitary papillary or polypoid lesions within the gall bladder. For this reason a solitary papillary or polypoid lesion can not be considered to be a primary tumour unless it also satisfies the other criteria.

Junctional activity is a prerequisite for the diagnosis of malignant melanoma of mucous surfaces, ${ }^{2122}$ and it was seen in six cases (table 1), including a unique case reported by Walsh ${ }^{5}$ in which, interestingly, the changes were present in the metaplastic squamous epithelium lining the gall bladder. We believe that the presence of junctional activity provides the most convincing evidence for the existence of primary malignant melanoma of the gall bladder, and we therefore consider that the six cases having this histological feature are true primary tumours. The absence of junctional changes in melanoma of the gall bladder, however, does not always exclude the possibility of its being a primary lesion because pre-existing junctional changes may be destroyed by the growth of the tumour.

In the cases where junctional activity was not recorded we attempted to exclude the presence of a primary tumour elsewhere. A history of skin lesions was obtained in only four of the cases ${ }^{40914}$ and examination of the skin and eyes was recorded in only eight. ${ }^{1-46111416}$ Examination of specimens obtained at necropsy excluded primary anal tumours in three ${ }^{126}$ and primary meningeal tumours in two. ${ }^{12}$ In three cases there was no mention of any attempt to exclude another primary site. ${ }^{911}{ }^{12}$ Although this does not mean that the melanomas could not originate in the gall bladder, it does cast doubts on the assumption, particularly if metastatic disease was noted at the time of presentation. An additional reason for excluding five cases was that the diagnosis was made at necropsy ${ }^{1-369}$ : it is likely that these patients died of disseminated disease that also affected the gall bladder.

All six of the tumours that we have accepted as primary tumours conformed to our criteria. Of those satisfying the first criteria but not the second, the information documented was not sufficiently detailed to allow us to exclude an alternative primary site. No metastatic tumours were reported as displaying junctional activity.
We believe that the present case was a true primary malignant melanoma of the gall bladder because it was a solitary mucosal lesion that displayed junctional activity on histological examination. In addition, the disease was diagnosed after cholecystectomy and a careful search for abdominal disease at the operation, as well as subsequent careful examination of the skin and extracutaneous sites where primary melanomas usually occur, had failed to show any tumour deposits. The patient gave no history of having had a skin lesion removed or of one that could have been regarded as a regressed melanoma. We are in no doubt that the gastric mucosal deposits that developed postoperatively and discovered at routine endoscopy are metastatic. They are multiple, small, have no junctional activity, and to our knowledge primary melanoma of the stomach has never been described. We did not consider lumbar puncture to be justified when the patient presented initially (particularly in the absence of symptoms). Now that he has clinical and cytological evidence of malignant meningitis we have a possible alternative site for a primary tumour because primary malignant melanoma of the brain and meninges metastasising outside the central nervous system is well known. ${ }^{262728}$ The brain and meninges are, however, more commonly a site for secondary deposits. ${ }^{29}$ Furthermore, in view of the seven months that elapsed between the diagnosis of the tumour in theo gall bladder and the appearance of meningeal symp toms, we believe that the meningeal deposits are secondary.

Of five patients presenting with acute cholecystitis (table 1), only the present case had a perforated gall bladder. This perforation was associated with an acute inflammatory reaction at a site distant from the growth. The presence of many eosinophilic polymorphs raises the possibility of a tissue eosinophilia associated with the tumour. Although malignant melanoma is not a recognised cause of this, ${ }^{30}$ there have recently been two reports of an association..$^{31}$ "Eosinophilic cholecystitis" has been described but does not seem to be a separate entity.$^{33}$ Perforation has important implications for the prognosis in that it allows shed tumour cells to seed throughout the peritoneal cavity. In one report ${ }^{17}$ mucosal implantation accounted for tumour deposits developing in the common bile duct nine months after cholecystectomy.

In contrast to carcinomas of the gall bladder, primary malignant melanomas of the gall bladder do not seem to be associated with cholelithiasis (table 1).

Distinguishing primary from secondary melanoma of the gall bladder is an academic exercise. Although the numbers of reported cases are small and there is one notable long term survivor ${ }^{6}$ (table 2 ), the prognosis is poor and the patients usually die of metastatic disease. 
We thank Mr SJS Kent for permission to report a patient under his care, to Professor G Rees, Dr J Kuzemko, and Dr P Van Der Bent for translations, Mr S Reddin for the illustrations and Dr M Dronfield, Dr A Stevens and Mr SJS Kent for helpful comments on the manuscript.

\section{References}

1 Weitung $\mathrm{H}$, Hamdi. Uber die physiologische und pathologische melaninpigmentierung und den epithelialen usprung der melanoblastome ein primares melanoblastome der gallenblase. Bietr Path Anat 1907;42:23-84.

2 Rosenthal SR. Primary melanocarcinoma of the gallbladder. American Journal of Cancer 1931;15:2289-300.

3 Pautler EE, Gallavan EM. Primary melanocarcinoma of the gallbladder. Archives of Pathology 1951;51:238-45.

4 Thayer KH, Williams OO, Rowe D. Malignant melanoma of the gallbladder. Ariz Med 1955;12:15-8.

5 Walsh TS. Primary melanoma of the gallbladder with cervical metastases and fourteen and a half years survival. Cancer 1956;6:518-22.

6 Jones CH. Malignant melanoma of the gallbladder. $J$ Pathol Bacteriol 1961;81:423-30.

7 Raffensperger EC, Branson FW, Triano G. Primary melanoma of the gallbladder. Am J Dig Dis 1963;8:356-63.

8 Debiec H, Kirylowicz K, Herba Z. Dwa przypadki czerniaka zlosliwogo pecherzka zolciowego. Przegl Lek 1966;6:463-5.

9 Simmard C, George P, Cautlet T, et al. Les melanomes malins de la vesicule bilaire. J Chir 1966;92:51-8.

10 Sierra-Callejas JL, Warecka K. Primary malignant melanoma of the gallbladder. Virchows Arch (Pathol Anat) 1976;370:233-8.

11 Pieson B, Rabbin L. Malignant melanoma of the gallbladder. Cancer 1976;37:2448-54.

12 Hatae Y, Kikuchi M, Segawa M, et al. Malignant melanoma of the gallbladder. Pathol Res Pract 1978;163:281-7.

13 Carle G, Lessels M, Best P. Malignant melanoma of the gallbladder: report of a case. Cancer 1981;48:2318-22.

14 Boria SR, Meyer WR, Cahill JP. Malignant melanoma of the gallbladder: report of a case. Cancer 1984;54:929-31.

15 Seul B, Luchtrath H. Malignes melanomes der gallenblase. Chirurg 1984;55:179-81.

16 Rudolph A, Bothe J, Bonk U. Malignes melanom der gallenblase. Chirurg 1985;56:469-71.
17 Verbanck JJ, Rutgeerts LJ, Van Aelst, et al. Primary MMGB, metastatic to the common bile duct. Gastroenterology 1986;91:214-18.

18 Das Gupta T, Brasfield R. Metastatic melanoma: a clinicopathological study. Cancer 1964;17:1323-39.

19 Breatnach AS. Normal and abnormal melanin pigment of the skin. In: Wolman M, ed. Pigments in pathology. Vol 1. New York: Academic Press 1969:335.

20 Le Douarin NM. Cell migration in embryos. Cell 1984;38:353-60.

21 Allen AC, Spitz S. Malignant melanoma: a clinicopathological analysis of the criteria for diagnosis and prognosis. Cancer 1953;6:1-13.

22 Raven RW, Dawson IMP. Malignant melanoma of the oesophagus. Br J Surg 1964;51:551-5.

23 Willis RA. The spread of tumours in the human body. London: Butterworths, 1952:219.

24 McFadden PM, Krementz ET, McKinnon WMP, Parora LL, Ryan RF. Metastatic melanoma of the gallbladder. Cancer 1979:44:1802-8.

25 Rosai J. Ackerman's surgical pathology. Vol 1. 6th ed. St Louis: CV Mosby, 1981:661.

26 Tolnal G, Campbell JS, Hill DP, et al. Primary malignant melanomatosis of the leptomeninges. Arch Neurol 1966;15: 404-9.

27 Bergdahl L, Boquist B, Liliequist B, et al. Primary malignant melanoma of the central nervous system. Acta Neurochir 1972:26:139-49.

28 Pasquier B, Couderc P, Pasquier D, et al. Primary malignant melanoma of the cerebellum: a case metastasising outside the nervous system. Cancer 1978;41:344-51.

29 Symmers WSC. Systemic pathology. Vol 5. 2nd ed. London: Churchill Livingstone, 1979:2221.

30 Lowe D, Jorizzo J, Hutt MSR. Tumour-associated eosinophilia: a review. J Clin Pathol 1981;34:1343-8.

31 Dincsoy HP, Burton TJ, Van Der Bel-Khan JM. Circulating Charcot-Leyden crystals in the hypereosinophilic syndrome. Am J Pathol 1981;75:236-43.

32 Siebenschein R, Siebenmann RE. Paraneoplastiche eosinophilies Leukemoid mit Thromboendocarditis parietalis: eosinophia bie malignen melanom. Schweiz Med Wochenschr 1977;107: 1257-65.

33 Fox H, Mainwaring AR. Eosinophilic infiltration of the gallbladder. Gastroenterology 1972;63:1049-51.

Requests for reprints to: Mr DI Heath, Department of Surgery, Glasgow Royal Infirmary, Glasgow G4 OSF, Scotland. 